\title{
PROSPECTIVE EVALUATION OF CLINICAL PROFILE AND TREATMENT OUTCOME OF PATIENTS PRESENTING WITH POLYARTHRITIS DIAGNOSED AS RHEUMATOID ARTHRITIS
}

\author{
Arpana Neopane ${ }^{1}$, Mona Sharma ${ }^{1}$, Sumugdha Rayamajhi ${ }^{1}$ \\ Department of Medicine, Kathmandu Medical College
}

\begin{abstract}
Introduction: Polyarthritis is a common presentation of patients attending medicine outpatient department. Among various causes Rheumatoid arthritis is the commonest and a well established case has distinct characteristic features. However the early presentation of this disease has not been clear thus leading to delay in treatment. The objectives of this study was to identify the various causes of polyarthritis in our clinical practice, discuss the varied clinical presentation of rheumatoid arthritis including early Rheumatoid arthritis and to evaluate the treatment response during one year follow up.
\end{abstract}

Methods: Prospective longitudinal study conducted in a teaching hospital over a two years period

Results: Rheumatoid arthritis was the commonest cause of polyarthritis (77.8\%) with a period prevalence of $0.7 \%$. Early presentation included atypical features like asymmetry, unilateral presentation, manifesting within 2 months to 2 years of diagnosis. $43 \%(n=18)$ of the patients had swelling and tenderness in overused joints 1.5 years prior to full clinical manifestation. Flitting or migratory joint pain not considered to be a feature of rheumatoid arthritis was also present in $14.3 \%(n=6)$ patients with mean duration of 1.5 years prior to full blown presentation. MCPJ (metacarpophalyngeal joints) and PIP (proximal interphalyngeal joints) were involved in 90\%. Treatment response with Methotrexate as a single DMARD was good as compared with DAS 28 ESR score.

Conclusions: RA is a common arthritis with varied clinical presentation. Recognition of early symptoms is needed for early diagnosis and initiation of DMARD. Methotrexate as a DMARD is effective and should be initiated early.

Key Words: Rheumatoid arthiris, Polyarthiris, DMARD.

\section{INTRODUCTION}

Joint Pain is one of the common complaints of patients visiting a clinician. Apart from nonspecific arthralgia, a significant number of patients present with inflammatory arthritis. Inflammatory arthritis is a condition characterized by pain and swelling in the joints associated with limitation of movements. The most common cause of chronic inflammatory arthritis is rheumatoid arthritis (RA) with a worldwide prevalence of $0.5 \%-1 \%$ of adult population'. Typically beginning in multiple small joints of the hands and feet in a symmetric fashion, RA has many variations, including months or years of recurrent monoarthritis (palindromic rheumatism) ${ }^{2}$ before a typical pattern evolves. Disease duration of 12 weeks or more is strongly predictive of persistent RA ${ }^{3 .}$ The symmetry of RA

\section{Correspondence:}

Dr. Arpana Neopane

Department of Medicine, Kathmandu Medical College, Sinamangal. E-mail: arpana.neopane@gmail.com

Cell No.: 9841230067 
is sometimes overemphasized, and it must be appreciated that this is a general, rough symmetry. RA can have unilateral manifestation ${ }^{4,5}$ and early RA may have varied presentations not abiding with the American College of Rheumatology (ARA) criteria or the American College of Rhematological Diseases (ACR, 1988) criteria ${ }^{6}$.

Though RA is the most common cause of polyarthritis, many other causes are also encountered time and again. While some of the arthritis like Ankylosing spondylitis is difficult to treat and also very difficult to prevent from progressing, others like arthritis due to rheumatic fever, gout can be prevented and treated ${ }^{7,8}$. In this context tuberculosis is worth mentioning in Asian population. It can present with symmetrical polyarthritis known as Poncets disease ${ }^{9,10}$. It responds to antitubercular therapy and heals without residual disease. Rheumatoid arthritis can also be remarkably controlled with disease modifying drugs, if detected early and treated before joint damage has occurred ${ }^{11,12}$.

Even though arthritis is common, study in this field is lacking in our country. Only recently have few specialist trained in rheumatology, started rheumatologic practice in Nepal. We do not have practice guide lines and management protocol as our cohorts of patients have not been studied. Hence a need for prospective study of this group of patient was needed.

The aim of this study was to diagnose various types of arthritis encountered in our population and to evaluate the various clinical presentations of rheumatoid arthritis. Early rheumatoid arthritis that does not exactly fit into the $\mathrm{ACR}^{13,14}$ criteria is largely missed and treated as nonspecific arthritis. We also want to evaluate the clinical presentation of this group of patients and highlight the early presentation. Similarly as the onset and progress of joint deformity and destruction in RA is directly related with early diagnosis and therapy this study also tries to assess the response of anti-rheumatoid drugs in our patients with use of locally available drugs.

\section{METHOD}

All patients presenting to the medical outpatient department of a medical college hospital with history of joint pain and swelling of more than two joints, for more than two weeks duration, were prospectively enrolled in the study period of April 2008 to April 2010. A detailed history was taken and examination done by a single experienced clinician. Patient characteristics included were mode of onset, duration of joint pain, morning stiffness, number of joints and joint areas involved, involvement of small joints of the hands and feet, presence or absence of axial joint involvement and sacroilitis, presence of tenderness, swelling and synovitis.
All were assessed for presence of nodules, rash and extraarticular features including all system. For laboratory investigation complete blood count and ESR, and specific investigations were sent if needed on the first day and data entered on day eight after reports were collected. All patients with clinical diagnosis of rheumatoid arthritis were diagnosed as per The American Rheumatism Association 1987 revised criteria for the classification of rheumatoid arthritis ${ }^{4,12}$ and those with early incomplete criteria were diagnosed with presence of seropositivity. Seropositivity defined as presence of RA factor $(\lg M)^{13}$, $14,15,16,17>60$ units and or A-CCP ${ }^{18,19,}$ (anti citrullinated cyclic peptide antibody), titer $>15$ units done by Elisa assay in a standard laboratory. Ankylosing Spondylitis and seronegative spondyloarthritis was diagnosed on the basis of presence of sacroilitis, buttock pain and nocturnal awakening with back pain, morning stiffness more than 30 minutes and family history ${ }^{20}$. Diagnosis of tuberculosis was considered if arthritis was present along with evening rise of temperature and showed positive mantoux test of $>20 \mathrm{~mm}$ with or without presence of erythema nodosum and phlyctenular conjunctivitis ${ }^{9,10}$. Rheumatic fever was diagnosed by Jones criteria ${ }^{21}$. Arthritis with features of connective tissue diseases other than RA were grouped as other connective tissue diseases. Gouty arthritis and non specific reactive arthritis were grouped as "others". All the patients with newly diagnosed rheumatoid arthritis were evaluated by DAS 28 ESR $^{22}, 23,24,25,26,27,28$ score after six weeks of persistent arthritis ${ }^{13}$ and started on methotrexate at loading dose of $15 \mathrm{mg} /$ week $^{28,29}$. Those who had long duration of disease and had DAS $28>5.1$ at presentation were started on more than two DMARD including hydroxychloroquine $400 \mathrm{mg}$ and sulfasalazine $1 \mathrm{gm}^{30,31}$. Follow up evaluation was done at 6 weeks, three months, six months and one year. All were instructed to visit in between if any drug complications arose or break through pain occurred. Treatment response in rheumatoid arthritis was defined as the improvement in DAS 28 score by $>1.2$ from baseline score ${ }^{23}$. The dose of methotrexate was tapered if possible to lowest $7.5-10 \mathrm{mg} /$ week if sustained response was seen, after six months. The scoring was done at three, six and 12 months but comparison was done between the third and the 12 months score. They were allowed to have NSAID as needed but frequency restricted to 1-3 times per week and if frequency was more than that, was asked to report when short course steroid was initiated. Maximum dose of methotrexate was $20 \mathrm{mg} /$ week, Hydroxychloroquin was $400 \mathrm{mg} /$ day with Salphasalazine at $2 \mathrm{gm}$ per day. Patients having DAS score $>6.1$ at the onset were allowed to have steroids ${ }^{30}$, ${ }^{31}$ for 7-10 days in a tapering dose. Steroid injections were allowed for few swollen joints at the time of follow up. All the data were entered in to the data sheet of SPSS version 17 and data analysis for relevant variables were done using descriptive statistics and t- test as required. 


\section{RESULTS}

A total of 54 patients presenting with inflammatory polyarthritis were enrolled. Rheumatoid arthritis was the most common arthritis and constituted $77.8 \%(n=42)$ with a period prevalence of $0.7 \%$ and was followed by seronegative spondyloarthritis (Fig.1). Tuberculosis presenting as polyarthritis was consistently associated with fever, erythema nodosum and positive ulcerative mantoux test with reading $>20 \mathrm{~mm}$. Mean age of the patients in RA group was $51.95 \pm 2.9$ and non RA group was $31.92 \pm 6.13$ (Fig 2). There were 32 females and 22 males in the study group. Female and male ratio in the rheumatoid group was 1.8:1 and 1.4:1 in non RA group. Clinical presentation and comparison between the RA and Non RA group is shown in Table1. Morning stiffness > $45 \mathrm{mins}$, involvement of more than two joint areas, boggy synovial swelling of the joints and joint deformities were significantly present in the RA group ( $p>.05)$. Rheumatoid nodules were present in only $11.9 \%(n=5)$ of RA patients.

Patients presenting with early rheumatoid arthritis had varied clinical presentation (Table. 2) which manifested within a mean duration of two months to two years before diagnosis. Interestingly $43 \%(n=18)$ of the patients had swelling and tenderness in overused joints almost 1.5 years prior to full clinical manifestation. Flitting or migratory joint pain not considered to be a feature of rheumatoid arthritis was also present in $14.3 \%(n=6)$ patients with mean duration of 1.5 years prior to full blown presentation.

In the rheumatoid group the MCPJ (metacarpophalyngeal joints) and PIP (proximal interphalyngeal joints) were involved in $90 \%$, followed by wrist $80 \%$, elbow $60 \%$ knee $60 \%$ (Table. 3). Para-articular site soft tissue involvement

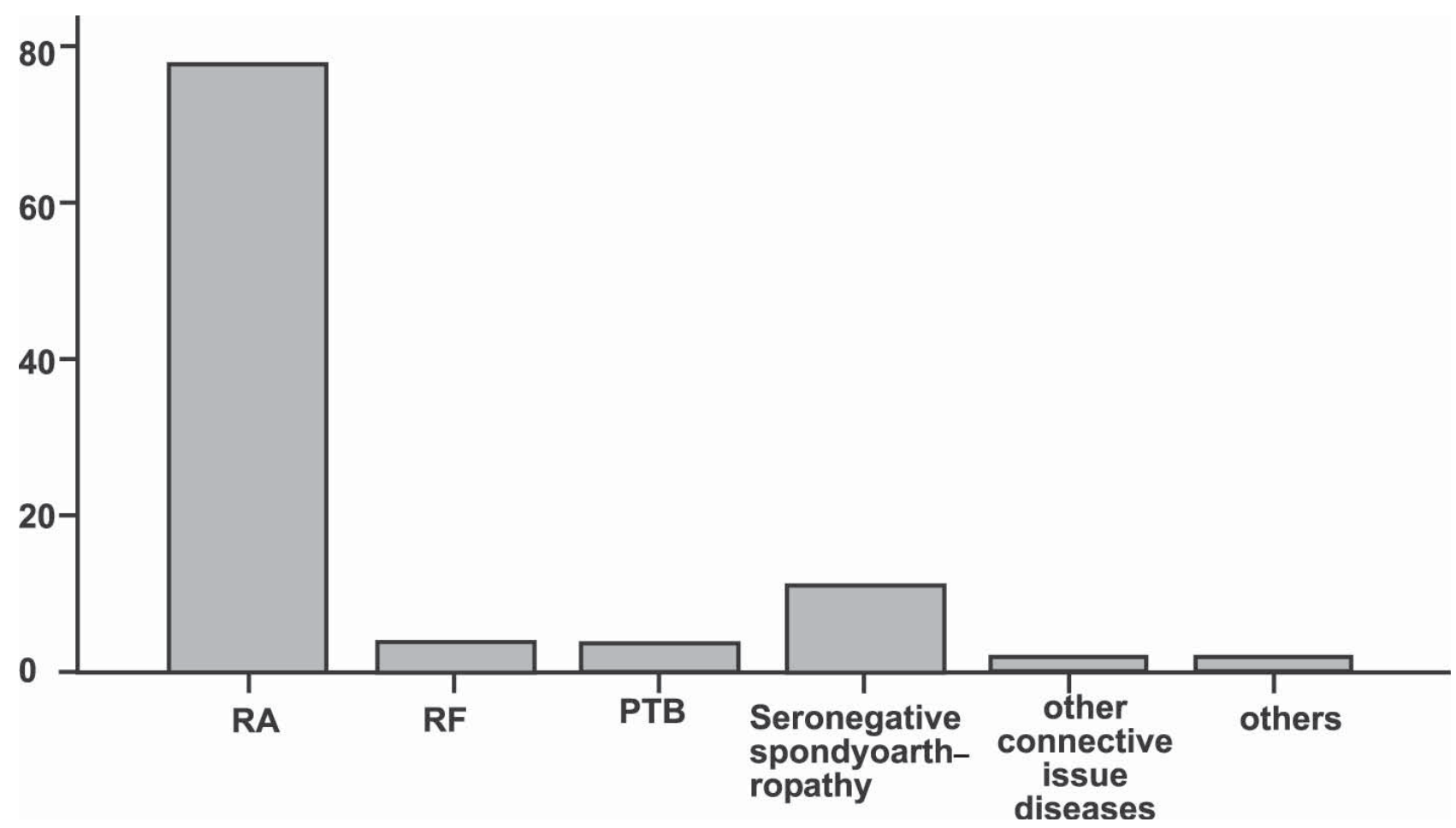

Fig: 1 Different causes and percentage of polyarthritis

manifested as repeated chest pain, upper back pain, throat and anterior neck pain sometimes confused as thyroiditis and pharyngitis. Extraarticular manifestations in our cohorts of RA cases were not significant. One patients had pericarditis and pericardial effusion. 9.5\% $(n=4)$ had sicca syndrome with severe dryness of eye proved by Schirmers tear test. Two patients had fine inspiratory crepts at ling bases without clinical symptoms and only mild evidence of restrictive lung disease in spirometry test. All these had disease duration of more than five years.
Regarding treatment Methotrexate as a DMARD was very effective and tolerated in our cohort of RA. None of the patients had to be discontinued due to side effects. Mean DAS 28 score on the second follow up was significantly lower $(p=<.05)$ compared with the DAS 28 score on the first follow up (Table.4) similarly patients on one DMARD ( methotrexate) had disease control comparable to more than two DMARD and increasing the number of DMARD did not show statistically significant disease control $(p=0.95)$. 


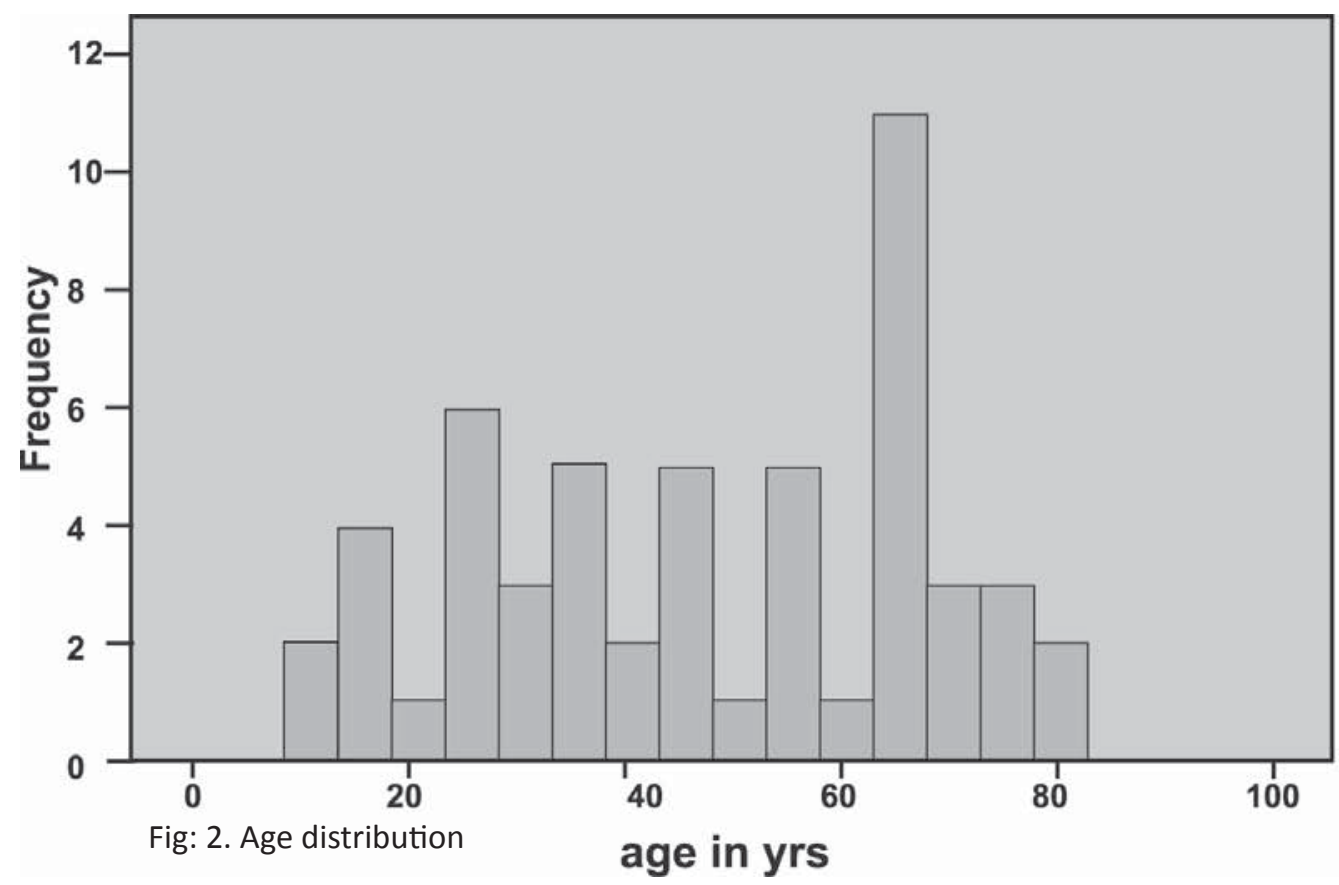

Mean $=47.24$

Std. Dev. $=20.711$

$\mathrm{N}=34$

Table 2: Early presentation of rheumatoid arthritis

\begin{tabular}{|c|c|c|c|c|}
\hline $\begin{array}{l}\text { Clinical profile } \\
\text { Mean age } \pm \text { SE }\end{array}$ & Parameters & $\begin{array}{l}\text { Rheumatoid } \\
\text { arthritis group } \\
\mathrm{N}=42 \\
51.95 \pm 2.9\end{array}$ & $\begin{array}{l}\text { Non rheumatoid arthritis } \\
\text { group } \\
\mathrm{N}=12 \\
31.92 \pm 6.13\end{array}$ & $p=\left(x^{2}\right)$ \\
\hline $\begin{array}{l}\text { Duration from onset } \\
\text { Of typical presentation }\end{array}$ & $\begin{array}{l}<\text { one year } \\
1-5 y r s \\
>5 y r s \\
>10 \text { yrs }\end{array}$ & $\begin{array}{l}19 \\
8 \\
13 \\
2\end{array}$ & $\begin{array}{l}10 \\
2 \\
0 \\
0\end{array}$ & .077 \\
\hline morning stiffness & $\begin{array}{l}\text { No morning stiffness } \\
<30 \text { mins } \\
>45 \text { mins }\end{array}$ & $\begin{array}{l}1 \\
8 \\
33\end{array}$ & $\begin{array}{l}0 \\
10 \\
2\end{array}$ & .042 \\
\hline Axial joint involvement & $\begin{array}{l}\text { Not involved } \\
\text { Involved }\end{array}$ & $\begin{array}{l}38 \\
4\end{array}$ & $\begin{array}{l}4 \\
8\end{array}$ & .00 \\
\hline $\begin{array}{l}\text { number of joint areas } \\
\text { involved }\end{array}$ & $\begin{array}{l}<4 \\
4-6 \\
>6\end{array}$ & $\begin{array}{l}5 \\
12 \\
25 \\
\end{array}$ & $\begin{array}{l}7 \\
4 \\
1\end{array}$ & .001 \\
\hline $\begin{array}{l}\text { presence of boggy synovial } \\
\text { swelling }\end{array}$ & $\begin{array}{l}<2 \\
2-4 \\
>4\end{array}$ & $\begin{array}{l}6 \\
15 \\
21\end{array}$ & $\begin{array}{l}7 \\
4 \\
1\end{array}$ & .003 \\
\hline deformity in the joints & $\begin{array}{l}\text { None } \\
<4 \\
>4\end{array}$ & $\begin{array}{l}17 \\
8 \\
17\end{array}$ & $\begin{array}{l}9 \\
1 \\
2\end{array}$ & .006 \\
\hline Nodules & Absent Present & $\begin{array}{l}37 \\
5\end{array}$ & $\begin{array}{l}7 \\
5\end{array}$ & .019 \\
\hline Fever at onset & $\begin{array}{c}\text { Absent } \\
\text { Present }\end{array}$ & $\begin{array}{l}37 \\
5\end{array}$ & $\begin{array}{l}9 \\
3\end{array}$ & .26 \\
\hline Flitting pain & $\begin{array}{l}\text { Absent } \\
\text { Present }\end{array}$ & $\begin{array}{l}36 \\
6\end{array}$ & $\begin{array}{l}7 \\
5\end{array}$ & .038 \\
\hline RA titre $>60 \mathrm{iu} / \mathrm{dl}$ & $\begin{array}{l}\text { Present } \\
\text { Absent }\end{array}$ & $\begin{array}{l}32 \\
10\end{array}$ & $\begin{array}{l}2 \\
10\end{array}$ & .001 \\
\hline
\end{tabular}

Medical Journal of Shree Birendra Hospital 


\begin{tabular}{|c|c|c|c|c|}
\hline & \begin{tabular}{|c|} 
Duration(mean) before \\
diagnosis (years)
\end{tabular} & Symmetry Yes & No & No of patients $n=(\%)$ \\
\hline $\begin{array}{l}\text { Morning stiffness }<30 \\
\text { mins }\end{array}$ & $1.5 \mathrm{yrs}$ & 4 & & $7(16.6)$ \\
\hline $\begin{array}{l}\text { Tenosynovitis of the hands } \\
\text { with swelling }\end{array}$ & 0.5 yrs & 6 & & $8(19)$ \\
\hline $\begin{array}{l}\text { Swelling and tenderness in } \\
\text { overused joints }\end{array}$ & 0.5 yrs & 18 & & $18(43)$ \\
\hline Supraspinatus tendinitis only & $2.0 \mathrm{yrs}$ & 4 & & $4(9.5)$ \\
\hline Acute severe polyarthritis & $0.2 y r s$ & 4 & & $4(9.5)$ \\
\hline $\begin{array}{l}\text { Throat pain on swallowing } \\
\text { and anterior neck pain }\end{array}$ & $1.0 \mathrm{yr}$ & 2 & & $2(5)$ \\
\hline Flitting pain & $1.5 \mathrm{yrs}$ & 6 & & $6(14.3)$ \\
\hline $\begin{array}{l}\text { Temporo-mandibular joint } \\
\text { Joint arthritis }\end{array}$ & $2.0 \mathrm{yrs}$ & 7 & & $7(16.6)$ \\
\hline $\begin{array}{l}\text { Chest pain with enthesitis on } \\
\text { off }\end{array}$ & $1 y r s$ & 3 & & $3(7.1)$ \\
\hline
\end{tabular}

Table : 3 Joints involvement in rheumatoid artrhitis

\begin{tabular}{|l|l|l|l|l|l|l|l|l|l|l|l|l|}
\hline $\begin{array}{c}\text { Joints } \\
\text { involved }\end{array}$ & MCP, PIP & Wrists & Knees & Shoulders & Ankles & Feet & Elbows & Hips & TMJ & spine & $\begin{array}{c}\text { Sternoclavicular } \\
\text { joint }\end{array}$ & $\begin{array}{c}\text { Para articular } \\
\text { sites }\end{array}$ \\
\hline$\%$ & 90 & 80 & 60 & 60 & 30 & 36 & 64 & 24 & 10 & 5 & 2 & 27 \\
\hline Number & 38 & 34 & 25 & 25 & 13 & 15 & 27 & 8 & 14 & 2 & 3 & 11 \\
\hline
\end{tabular}

MCP: Metacarpophalangeal joint. PIP: Proximal Interphalangeal joint. TMJ: Temporomadibular joint.

Table 4: Drug response in Rheumatoid arthritis

\begin{tabular}{|c|c|c|c|c|c|}
\hline $\begin{array}{l}\text { Outcome } \\
\text { group }\end{array}$ & Treatment response $(n=)$ & $\begin{array}{l}\text { DAS } 28 \text { ESR } \\
\text { score } \\
\text { Mean }+ \text { SE }\end{array}$ & Test of significance & $\begin{array}{l}\text { Significance } \\
P=\end{array}$ & $95 \% \mathrm{Cl}$ \\
\hline 1. & $\begin{array}{l}\text { DAS } 28 \text { at first follow up }(n=42) \\
\text { DAS } 28 \text { at second follow up }(n=42)\end{array}$ & $\begin{array}{l}6.80 \pm .22 \\
3.52 \pm .34\end{array}$ & $\begin{array}{l}\text { Paired sample correlation } \\
4.28\end{array}$ & .005 & \\
\hline 2. & $\begin{array}{l}\text { DAS } 28 \text { score difference in two } \\
\text { group }(n=42)\end{array}$ & $2.5 \pm .24$ & $\begin{array}{l}\text { One tailed t-test } \\
t=10.9 \\
d f=41\end{array}$ & $<.001$ & 2.11-3.06 \\
\hline 1. & $\begin{array}{l}\text { DAS } 28 \text { score difference with one } \\
\text { DMARD }(n=28)\end{array}$ & $2.58 \pm 0.28$ & $\begin{array}{l}t=0.051 \\
d f=40\end{array}$ & 0.95 & $-1.05-1$ \\
\hline 2. & $\begin{array}{l}\text { DAS } 28 \text { score difference with more } \\
\text { than one } \\
(n=14)\end{array}$ & $2.6 \pm 0.45$ & & & \\
\hline
\end{tabular}




\section{DISCUSSION}

Rheumatoid arthritis was the most common causes of inflammatory arthritis in our population. In our study the in hospital period prevalence was $0.7 \%$ which is comparable to the prevalence in other studies. Females were more affected than male but the ratio was less than quoted in other studies ${ }^{16,17}$. Among other causes of inflammatory arthritis, Spondylotic arthritis was the second most common as in other studies ${ }^{18,19}$. Primary tuberculosis also presented as polyarthritis and was associated with boggy synovial swelling of multiple joints, mainly involving the wrist and ankle and was seen in young females. The presentation was typical of Poncet's reactive arthritis ${ }^{20,21}$.

Regarding clinical features in rheumatoid arthritis (Table.2), those presenting within one year of onset of joint pain had characteristic features. Significant number of patients presented with unilateral symptoms and had morning stiffness less than $\mathbf{3 0}$ mins. Some of the patients presented with chondral site pain like anterior neck pain with tenderness over the hyoid bone and cricoids cartilage and difficulty in swallowing. Temporomandibular arthritis $^{32}$ was the symptoms that had a prolonged onset with a mean duration of 1.9 years before full blown presentation. Low back pain was also present in some patients diagnosed as RA.

Joint involvement in RA was almost similar to other studies with the MCP and PIP involved in maximum number of patients (Table 3 ). However systemic and extra-articular manifestation was negligible in our cohort of patients with RA. Interestingly after one year follow up, two of our patients died. One male RA patient died due to pericardial tamponade and a female with coexistent COAD died due to bronchogenic carcinoma which manifested almost 6 months after the patients initiation on methotrexate, compelling us to diagnose RA presenting as a paraneoplastic syndrome $\mathrm{e}^{33}$.

Regarding treatment our group of patients responded very well to Methotrexate ${ }^{29,30}$ and there was not much difference between the one DMARD and more than one DMARD group ${ }^{33,34}$ (Table.4). Apart from intermittent diarrhea and oral ulcers none of the patients reported much adverse effect. Those patients responding to methotrexate did fine with good treatment response at a dose ranging from $10 \mathrm{mg} /$ week to $15 \mathrm{mg} /$ week. Those not showing response and requiring repeated NSAID and short course steroid (7-10 days) for more than three times in six months period did not improve significantly $(p=.95)$ with three DMARD.

Due to practical problem we did not use radiological score to evaluate the response which may be the major drawback of our study. Treatment response was assessed using DAS28 ESR score and the mean difference in the score after treatment was significantly better (Table.5). As the treatment response in the group with more than one DMARD were not statistically different and they had to be put on intermittent steroid we want to infer that these patients may be the ones to improve on biological agents $^{35}$. But due to financial constraints and lack of fund we could not add biological agents to these patients and had to be satisfied with intermittent steroid and multiple DMARD though our study shows that they could have been managed on only methotrexate with intermittent steroid.

\section{CONCLUSION}

We conclude that RA is a very common disabling arthritis in our population, but reactive arthritis like tubercular arthritis may also present as polyarthritis similar to rheumatoid arthritis. Early presentation of RA may not fit in the typical ARA clinical criteria. Early diagnosis and treatment is essential to prevent joint damage. At this early stage serology may be helpful for diagnosis apart from the various presentations mentioned. Methotrexate is a very good drug for our population and adverse effect is not much. Since disease control is the goal of therapy intermittent steroid is very helpful. Patients not responding to multiple DMARD should be considered candidates for the biological agents along with methotrexate.

\section{REFERENCES}

1. Firestein: Kelly's text book of rheumatology. Ed 8th vol1. Chapter 66, 2008

2. Fleming $A$, Benn RT, Corbett $M$, et al: Early rheumatoid disease, II: Patterns of joint involvement. Ann Rheum Dis. 1976;35:361-64.

3. Guerne PA, Weisman MH. Palindromic rheumatism: part of or apart from the spectrum of rheumatoid arthritis. Am J Med. 1992;93(4):451-60.

4. Green M, Marzo-Ortega H, McGonagle D, Wakefield R, Proudman S, Conaghan P, Gooi J, Emery P. Persistence of mild, early inflammatory arthritis: the importance of disease duration, rheumatoid factor, and the shared epitope. Arthritis Rheum. 1999;42(10):2184-8.

5. Zangger P, Keystone EC, Bogoch ER. Asymmetry of small joint involvement in rheumatoid arthritis: prevalence and tendency towards symmetry over time. Joint Bone Spine. $2005 ; 72(3): 241-7$.

6. Fleming A., Benn R.T., Corbett M., et al: Early rheumatoid disease, II: Patterns of joint involvement. Ann Rheum Dis. 1976;35:361-64.

7. Banal F, Dougados M, Combescure C, Gossec L. Sensitivity and specificity of the American College of Rheumatology 1987 criteria for the diagnosis of rheumatoid arthritis according to disease duration: a systematic literature review and metaanalysis. Ann Rheum Dis. 2009;68(7):1184-91.

8. Schneider S, Schmitt G, Richter W. Prevalence and correlates of inflammatory arthritis in Germany: data from the First National Health Surve Rheumatol Int. 2006;27(1):29-38. 
9. Lawrence RC, Helmick CG, Arnett FC, Deyo RA, Felson DT, Giannini $\mathrm{EH}$, et al. Estimates of the prevalence of arthritis and selected musculoskeletal disorders in the United States. Arthritis Rheum. 1998;41:778-99.

10. Kroot EJ, Hazes JM, Colin EM, Dolhain RJ.Poncet's disease: reactive arthritis accompanying tuberculosis. Two case reports and a review of the literature. Rheumatology (Oxford). 2007;46(3):484-9.

11. Dall L, Long L, Stanford J. Poncet's disease: tuberculous rheumatism. Rev Infect Dis. 1989;11(1):105-7.

12. Nell, V. P. et al. Benefit of very early referral and very early therapy with disease-modifying anti-rheumatic drugs in patients with early rheumatoid arthritis. Rheumatology (Oxford). 2004;43:906-14.

13. Arnett FC, Edworthy SM, Bloch DA, McShane DJ, Fries JF, Cooper NS, Healey LA, Kaplan SR, Liang MH, Luthra HS, et al. The American Rheumatism Association 1987 revised criteria for the classification of rheumatoid arthritis. Ann Rheum Dis. 2009;68(7):1184-91.

14. Zhao J, Liu X, Wang Z, Li Z. Significance of anti-CCP antibodies in modification of 1987 ACR classification criteria in diagnosis of rheumatoid arthritis. Clin Rheumato.l 2010;29(1):33-8.

15. Gerber LH, Furst G, Yarboro C, el-Gabalawy H. Number of active joints, not diagnosis, is the primary determinant of function and performance in early synovitis. Clin Exp Rheumatol. 2003;21(5 Suppl 31):S65-70.

16. Nielen, M. M. et al. Specific autoantibodies precede the symptoms of rheumatoid arthritis: a study of serial measurements in blood donors. Arthritis Rheum.. 2004;50:380-86.

17. Ball J, Lawrence JS. The relationship of Rheumatoid arthritis serum factor to rheumatoid arthritis: a 5-year follow up of a population sample. Ann Rheum Dis. 1963;22:311-8.

18. Persselin JE. Diagnosis of rheumatoid arthritis. Medical and laboratory aspects. Clin Orthop Relat Res. 1991;265:73-82.

19. Nishimura K, Sugiyama D, Kogata Y, Tsuji G, Nakazawa T, Kawano S, Saigo K, Morinobu A, Koshiba M, Kuntz KM, Kamae I, Kumagai S. Meta-analysis: diagnostic accuracy of anti-cyclic citrullinated peptide antibody and Rheumatoid Factor for rheumatoid arthritis. Ann Intern Med. 2007;146(11):797-808.

20. Schellekens $G A$, Visser $H$, de Jong $B A$, van den Hoogen FH, Hazes JM, Breedveld FC, van Venrooij WJ. The diagnostic properties of rheumatoid arthritis antibodies recognizing a cyclic citrullinated peptide. Arthritis Rheum. 2000;43(1):15563.

21. Rudwaleit M, Metter A, Listing J, et al: Inflammatory back pain in ankylosing spondylitis: A reassessment of the clinical history for application as classification and diagnostic criteria. Arthritis Rheum. 2006;65:569-78.

22. Ferrieri P; Jones Criteria Working, Group (2002). "Proceedings of the Jones Criteria workshop". Circulation. 2002;106(19): 2521-3.

23. Panchagnula R, Rajiv SR, Prakash J, Chandrashekara $\mathrm{S}$, Suresh KP. Role of anticyclic citrullinated peptide in the diagnosis of early rheumatoid factor-negative suspected rheumatoid arthritis: is it worthwhile to order the test? J Clin Rheumatol. 2006;12(4):172-5.

24. Van der Heijde D.M., van't Hof M., van Riel P.L., et al: Development of a disease activity score based on judgment in clinical practice by rheumatologists. J
Rheumatol. 1993;20:579-81.

25. Felson D.T., Anderson J.J., Boers M., et al: Preliminary definition of improvement in rheumatoid arthritis. American College of Rheumatology. Arthritis Rheum. 1995;38:727-35.

26. Felson D.T., Anderson J.J., Boers M., et al: The American College of Rheumatology preliminary core set of disease activity measures for rheumatoid arthritis clinical trials. The Committee on Outcome Measures in Rheumatoid Arthritis Clinical Trials. Arthritis Rheum. 1993;36:729-40.

27. Van Gestel A.M., Prevoo M.L.L., Van't Hof M.A., et al: Development and validation of the European League against Rheumatism response criteria for rheumatoid arthritis. Arthritis Rheum. 1996;39:34-40.

28. Vrijhoef H.J.M., Diederiks J.P.M., Spreeuwenberg C., et al: Applying low disease activity criteria using the DAS28 to assess stability in patients with rheumatoid arthritis. Ann Rheum Disease. 2003;62:419-22.

29. Prevoo M.L.L., Van't Hof M.A., et al: Modified disease activity scores that include twenty-eight-joint counts: Development and validation in a prospective longitudinal study of patients with rheumatoid arthritis. Arthritis Rheum. 1995;38:44-8

30. van Dongen, $\mathrm{H}$. et al. Efficacy of methotrexate treatment in patients with probable rheumatoid arthritis: a doubleblind, randomized, placebo-controlled trial. Arthritis Rheum. 2007;56:1424-32.

31. Mottonen, T. et al. Delay to institution of therapy and induction of remission using single-drug or combination-diseasemodifying antirheumatic drug therapy in early rheumatoid arthritis. Arthritis Rheum. 2002;46:894-8.

32. John R. Kirwan, M.D., and the Arthritis and Rheumatism Council Low-Dose Glucocorticoid Study Group.The Effect of Glucocorticoids on Joint Destruction in Rheumatoid Arthritis. N Engl J Med. 1995;333:142-7

33. Boers M., Verhoeven A.C., Markusse H.M., et al: Randomised comparison of combined step-down prednisolone, methotrexate and sulphasalazine with sulphasalazine alone in early rheumatoid arthritis. Lancet. 1997;350:309-18.

34. Katchamart W, Trudeau J, Phumethum V, Bombardier C. Methotrexate monotherapy versus methotrexate combination therapy with non-biologic disease modifying anti-rheumatic drugs forrheumatoid arthritis. Cochrane Database Syst Rev. 2010;(4):CD008495.

35. Kuriya B, Arkema EV, Bykerk VP, Keystone EC. Efficacy of initial methotrexate monotherapy versus combination therapy with a biological agent in early rheumatoid arthritis: a metaanalysis of clinical and radiographic remission. Ann Rheum Dis. 2010;69(7):1298-304.

36. Finckh A, Bansback $N$, Marra $C A$, Anis $A H$, Michaud $\mathrm{K}$, Lubin S, White $\mathrm{M}$, Sizto $\mathrm{S}$, Liang $\mathrm{MH}$. Treatment of very early rheumatoid arthritis with symptomatic therapy, diseasemodifying antirheumatic drugs, or biologic agents: a costeffectiveness analysis. Ann Intern Med. 2009;151(9):612-21.

37. Singh JA, Christensen $R$, Wells GA, Suarez-Almazor ME, Buchbinder R, Lopez-Olivo MA, Tanjong Ghogomu E, Tugwell P. Biologics for rheumatoid arthritis: an overview of Cochrane reviews. Cochrane Database Syst Rev. 2009;(4):CD007848. 